\title{
Induksi Kalus dan Embrio Somatik Tanaman Jambu Biji Merah (Psidium guajava L.)
}

\section{Callus and Somatic Embryo Induction of Guava (Psidium guajava L.)}

\author{
Reza Ramdan Rivai ${ }^{1}$, Ali Husni ${ }^{2}$, Agus Purwito ${ }^{1 *}$
}

\begin{abstract}
${ }^{1}$ Departemen Agronomi dan Hortikultura, Fakultas Pertanian, Institut Pertanian Bogor (Bogor Agricultural University), Jl. Meranti, Kampus IPB Darmaga, Bogor 16680, Indonesia Telp.\&Faks.62-251-8629353 e-mail agronipb@indo.net.id ${ }^{2}$ Balai Besar Penelitian dan Pengembangan Bioteknologi dan Sumber Daya Genetik Pertanian, Kementerian Pertanian Republik Indonesia. Jl. Tentara Pelajar No. 3A. Bogor 16680, Indonesia *)Penulis untuk korespondensi : apurwito@yahoo.com
\end{abstract}

Disetujui 24 Desember 2013/ Published online 13 Februari 2014

\begin{abstract}
The objective of the research was to get the best protocol for callus and somatic embryo induction of guava. The experiment was conducted at Tissue Culture Laboratory, Department of Agronomy and Horticulture, Faculty of Agriculture, Bogor Agricultural University from September 2012 until March 2013. The research was arranged in to two experiments, that were callus induction for the first experiment and somatic embryo induction for the last one. The results showed that media with plant growth regulator composition treatments $R 1$ (5 $\left.\mathrm{mg} \mathrm{l}^{-1} 2.4-D\right), R 3\left(5 \mathrm{mg} \mathrm{l}^{-1} 2.4-D+1 \mathrm{mg} \mathrm{l}^{-1} B A P\right)$ and $R 6$ (2.5 mg l-1 2.4-D + 2 $\left.m g l^{-1} \quad 2-i P\right)$ were the best treatments for inducting compact callus in 4 weeks after culture (WAC). On the other hand, the friable callus can be induced at media with plant growth regulator composition treatment $R 5$ $\left(5 \mathrm{mg} \mathrm{l}^{-1} 2.4-D+2 \mathrm{mg} \mathrm{l}^{-1} 2-i P\right)$. In addition, the primary somatic embryos can be induced at the treatment $R 2 E 4$ (2.5 $\mathrm{mg} \mathrm{l}^{-1}$ 2.4-D was moved in to $\left.1 \mathrm{mg} \mathrm{l}^{-1} 2.4-D+2 \mathrm{mg} \mathrm{l}^{-1} 2-i P\right)$ and the treatment R5E4 (5 mg $\mathrm{l}^{-1}$ 2.4-D $+2 \mathrm{mg} \mathrm{l}^{-1} 2-i P$ was moved in to $\left.1 \mathrm{mg} \mathrm{l}^{-1} 2.4-D+2 \mathrm{mg} \mathrm{l}^{-1} 2-i P\right)$ in 12 and 16 WAC for each that treatment.
\end{abstract}

Keywords: callus, guava, plant growth regulator, somatic embryo.

\section{ABSTRAK}

Penelitian ini bertujuan untuk memperoleh protokol yang tepat dalam menginduksi kalus dan embrio somatik tanaman jambu biji merah. Penelitian ini dilaksanakan di Laboratorium Kultur Jaringan, Departemen Agronomi dan Hortikultura, Fakultas Pertanian, Institut Pertanian Bogor pada bulan September 2012 sampai dengan bulan Maret 2013. Penelitian tersusun atas dua percobaan yaitu percobaan pertama merupakan induksi kalus dan percobaan kedua merupakan induksi embrio somatik. Hasil penelitian menunjukkan bahwa media dengan perlakuan zat pengatur tumbuh $R 1$ (5 $\left.\mathrm{mg}^{-1} 2.4-D\right), R 3$ (5 $\mathrm{mg}^{-1}$ 2.4-D + $1 \mathrm{mg} \mathrm{l}^{-1}$ BAP) dan $R 6$ (2.5 $\mathrm{mg} \mathrm{l}^{-1}$ 2.4-D $\left.+2 \mathrm{mg} \mathrm{l}^{-1} 2-i P\right)$ merupakan perlakuan terbaik untuk menginduksi kalus kompak pada 4 minggu setelah tanam (MST), sedangkan untuk menginduksi kalus remah didapatkan media dengan perlakuan zat pengatur tumbuh terbaik yaitu $R 5\left(5 \mathrm{mg} \mathrm{l}^{-1} 2.4-\mathrm{D}+2 \mathrm{mg}^{-1} 2-i P\right)$. Embrio

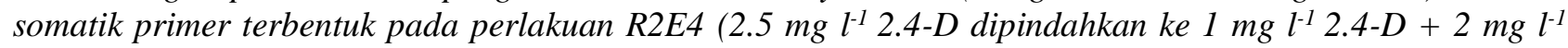
2-iP) dan perlakuan R5E4 (5 $\mathrm{mg} \mathrm{l}^{-1} 2.4-D+2 \mathrm{mg} \mathrm{l}^{-1} 2$-iP dipindahkan $\left.\mathrm{ke} 1 \mathrm{mg} \mathrm{l}^{-1} 2.4-D+2 \mathrm{mg}^{-1} 2-i P\right)$ masing-masing pada 12 dan 16 MST.

Kata kunci: embrio somatik, jambu biji, kalus, zat pengatur tumbuh.

\section{PENDAHULUAN}

Jambu biji merah merupakan salah satu komoditas hortikultura penting yang dapat dikonsumsi dalam bentuk segar maupun dalam bentuk olahan. Kandungan gizi jambu biji merah sangat tinggi terutama sumber vitamin C dibandingkan dengan buah lainnya. Selain itu, jambu biji merah mengandung serat, pektin dan tanin yang bermanfaat bagi kesehatan (Cahyono 2010). 
Jambu biji merah lokal Indonesia kurang mampu bersaing dengan jambu biji merah dari negara lain seperti Thailand karena kualitas buahnya yang relatif lebih rendah. Jumlah biji buah jambu biji merah lokal Indonesia umumnya lebih banyak sehingga daya saingnya lemah di pasar global. Perlu dilakukan pemuliaan jambu biji merah untuk meningkatkan kualitas buahnya.

Pemuliaan konvensional untuk mendapatkan kualitas buah yang lebih baik seperti buah tanpa biji relatif lama dan sulit dilakukan. Menurut Chandra et al. (2004) perakitan tanaman jambu biji merah tanpa biji dengan memanfaatkan teknik kultur jaringan khususnya penggunaan embrio somatik yang dimutasikan merupakan salah satu alternatif teknologi yang dapat digunakan. Sebelum dilakukan mutasi, perlu adanya protokol yang tepat untuk meregenerasikan tanaman jambu biji merah secara in vitro. Menurut Damayanti et al. (2007) regenerasi tanaman secara in vitro dapat dilakukan melalui beberapa cara diantaranya embriogenesis somatik dan organogenesis. Kelebihan metode embriogenesis somatik adalah mampu menghasilkan tanaman dalam jumlah banyak dengan waktu relatif singkat.

Menurut Lestari (2007) zat pengatur tumbuh merupakan salah satu faktor penting dalam induksi kalus dan penentuan arah regenerasi kalus menjadi tanaman. Evans et al. (2003) menyatakan bahwa zat pengatur tumbuh paling penting yang terlibat dalam arah regenerasi kalus menjadi tanaman pada kultur in vitro adalah auksin, sitokonin dan giberelin eksogen yang terkandung dalam media.

Penelitian ini bertujuan untuk memperoleh protokol yang tepat dalam menginduksi kalus dan embrio somatik tanaman jambu biji merah. Penelitian ini tersusun atas dua percobaan yaitu percobaan pertama merupakan induksi kalus dan percobaan kedua merupakan induksi embrio somatik. Keseluruhan percobaan menggunakan komposisi zat pengatur tumbuh yang berbeda sebagai faktor percobaan.

\section{BAHAN DAN METODE}

Penelitian dilakukan di Laboratorium Kultur Jaringan, Departemen Agronomi dan Hortikultura, Fakultas Pertanian, Institut Pertanian Bogor. Penelitian ini dilaksanakan pada bulan September 2012 sampai dengan bulan Maret 2013.

Bahan yang digunakan adalah biji muda dari buah jambu biji merah berumur \pm 1 bulan setelah antesis yang berasal dari Pusat Biofarmaka
IPB. Bahan sterilisasi eksplan yang digunakan adalah deterjen, antiseptik, kloroks $10 \%$ dan alkohol 96\%. Media tumbuh yang digunakan pada percobaan ini adalah media dasar MS (Murashige and Skoog), sukrosa, prolin, agar (bahan pemadat), aquades, arang aktif, zat pengatur tumbuh yang berasal dari golongan auksin yaitu 2.4-D (2.4-dichlorophenox acetic acid) dan NAA (naphthalene acetic acid), golongan sitokinin yaitu BAP (6-benzyl amino purine) dan 2-iP (N6-2isopentenyl adenine) serta dari golongan giberelin yaitu GA3.

Alat yang digunakan terdiri dari peralatan gelas (botol kultur, botol ukur, gelas piala, cawan petri, gelas ukur, dan corong gelas), kompor, autoklaf, laminar air flow cabinet, peralatan diseksi seperti pinset, gunting, dan scalpel. Pada saat kultur tanaman diperlukan rak dan ruang kultur bersuhu $18-21^{\circ} \mathrm{C}$.

Penelitian ini tersusun atas dua percobaan. Percobaan pertama yaitu induksi kalus menggunakan rancangan acak lengkap (RAL) satu faktor. Terdapat enam taraf komposisi zat pengatur tumbuh yaitu: (R1) $5 \mathrm{mg} \mathrm{l}^{-1} 2.4-\mathrm{D}$, (R2) $2.5 \mathrm{mg} \mathrm{l}^{-1}$ 2.4-D, (R3) $5 \mathrm{mg} \mathrm{l}^{-1} 2.4-\mathrm{D}+1 \mathrm{mg} \mathrm{l}^{-1} \mathrm{BAP}$, (R4) $2.5 \mathrm{mg} \mathrm{l}^{-1} 2.4-\mathrm{D}+1 \mathrm{mg} \mathrm{l}^{-1} \mathrm{BAP}$, (R5) $5 \mathrm{mg} \mathrm{l}^{-1} 2.4-$ $\mathrm{D}+2 \mathrm{mg} \mathrm{l}^{-1} 2-\mathrm{iP}$, (R6) $2.5 \mathrm{mg} \mathrm{l}^{-1} 2.4-\mathrm{D}+2 \mathrm{mg} \mathrm{l}^{-1}$ 2-iP. Terdapat 5 ulangan untuk masing-masing perlakuan sehingga terdapat 30 satuan percobaan (botol kultur). Tiap satuan percobaan terdiri dari 10 eksplan, sehingga terdapat 300 satuan amatan.

Percobaan kedua yaitu induksi embrio somatik menggunakan enam taraf asal kalus yang diperoleh dari percobaan pertama dan disubkultur pada lima taraf komposisi zat pengatur tumbuh yaitu: (E1) $1 \mathrm{mg} \mathrm{l}^{-1}$ 2.4-D, (E2) $1 \mathrm{mg} \mathrm{l}^{-1} 2.4-\mathrm{D}+1$ mg l-1 NAA, (E3) $1 \mathrm{mg} \mathrm{l}^{-1} 2.4-\mathrm{D}+1 \mathrm{mg} \mathrm{l}^{-1}$ BAP, (E4) $1 \mathrm{mg} \mathrm{l}^{-1} 2.4-\mathrm{D}+2 \mathrm{mg} \mathrm{l}^{-1}$ 2-iP dan (E5) $1 \mathrm{mg} \mathrm{l}^{-}$ ${ }^{1} 2.4-\mathrm{D}+1 \mathrm{mg} \mathrm{l}^{-1} \mathrm{GA} 3$. Terdapat 30 perlakuan dengan 5 ulangan untuk masing-masing perlakuan sehingga terdapat 150 satuan percobaan (botol kultur). Tiap satuan percobaan terdiri dari 2 eksplan sehingga terdapat 300 satuan amatan.

Data yang diperoleh dianalisis menggunakan metode deskriptif serta analisis ragam dengan uji $\mathrm{F}$ pada taraf nyata 5\%. Jika uji $\mathrm{F}$ berpengaruh nyata maka nilai tengah diuji lanjut dengan uji jarak berganda Duncan (Duncan Multiple Range Test/ DMRT) pada taraf nyata 5\%.

Pembuatan media MS dilakukan dengan mengambil larutan dari setiap larutan stok media (A, B, C, D, E, F, myoinositol, vitamin dan asam amino prolin) yang telah dibuat sesuai dengan volume yang diperlukan serta ditambah dengan zat pengatur tumbuh sesuai dengan perlakuan masing- 
masing. Setelah semua larutan dimasukkan ke dalam labu takar ditambahkan gula yang telah dilarutkan dengan konsentrasi $30 \mathrm{~g} \mathrm{l}^{-1}$. Lalu ditera sampai tanda tera dengan aquades. Setelah itu dilakukan pengukuran $\mathrm{pH}$ dengan kertas lakmus sampai $\mathrm{pH}$ media 5.8. Larutan media yang telah diukur $\mathrm{pH}$ dimasukkan kedalam panci lalu ditambahkan agar dengan konsentrasi $7 \mathrm{~g} \mathrm{l}^{-1}$ dan arang aktif sebanyak $2 \mathrm{~g} \mathrm{l}^{-1}$. Larutan media dimasak sampai mendidih. Larutan media lalu dimasukkan ke dalam botol kultur sekitar 25 $\mathrm{ml} /$ botol. Semua media disterilkan dalam autoklaf pada suhu $121^{\circ} \mathrm{C}$ dengan tekanan 17.5 Psi selama 25-30 menit.

Buah jambu biji merah direndam dalam larutan deterjen dan antiseptik selama 10 menit, kemudian dicuci dan disikat bersih dibawah air yang mengalir. Buah yang telah bersih dipindahkan ke laminar air flow cabinet dan dibilas menggunakan aquades. Buah direndam dan dikocok dalam larutan kloroks $10 \%$ selama 5 menit lalu dibilas menggunakan aquades sebanyak tiga kali. Buah dibakar di atas bunsen sebelum dipindahkan ke cawan petri.

Penanaman eksplan dilakukan di dalam laminar air flow cabinet yang telah dibersihkan dengan menggunakan alkohol 96\%. Buah jambu biji merah yang telah disterilisasi dipindahkan ke cawan petri, dibelah melintang dan diekstraksi bijinya serta ditanam pada media yang telah disiapkan. Satu botol terdiri atas 10 eksplan. Kultur disimpan dalam ruang kultur yang gelap dan bertemperatur $18-21^{\circ} \mathrm{C}$.

Peubah percobaan yang diamati pada percobaan pertama (induksi kalus) yaitu persentase kultur steril, persentase eksplan berkalus dan tipe kalus. Peubah percobaan yang diamati pada percobaan kedua (induksi embrio somatik) yaitu persentase kalus berakar, persentase eksplan berkecambah, rata-rata tinggi kecambah, persentase kalus embriogenik dan jumlah embrio somatik.

\section{HASIL DAN PEMBAHASAN}

\section{Percobaan 1: Induksi Kalus}

Penelitian yang terdiri atas dua percobaan, diawali dengan percobaan untuk menentukan media dengan komposisi zat pengatur tumbuh terbaik dalam menginduksi kalus dari eksplan biji muda. Peubah yang diamati pada percobaan pertama ini adalah persentase kultur steril.

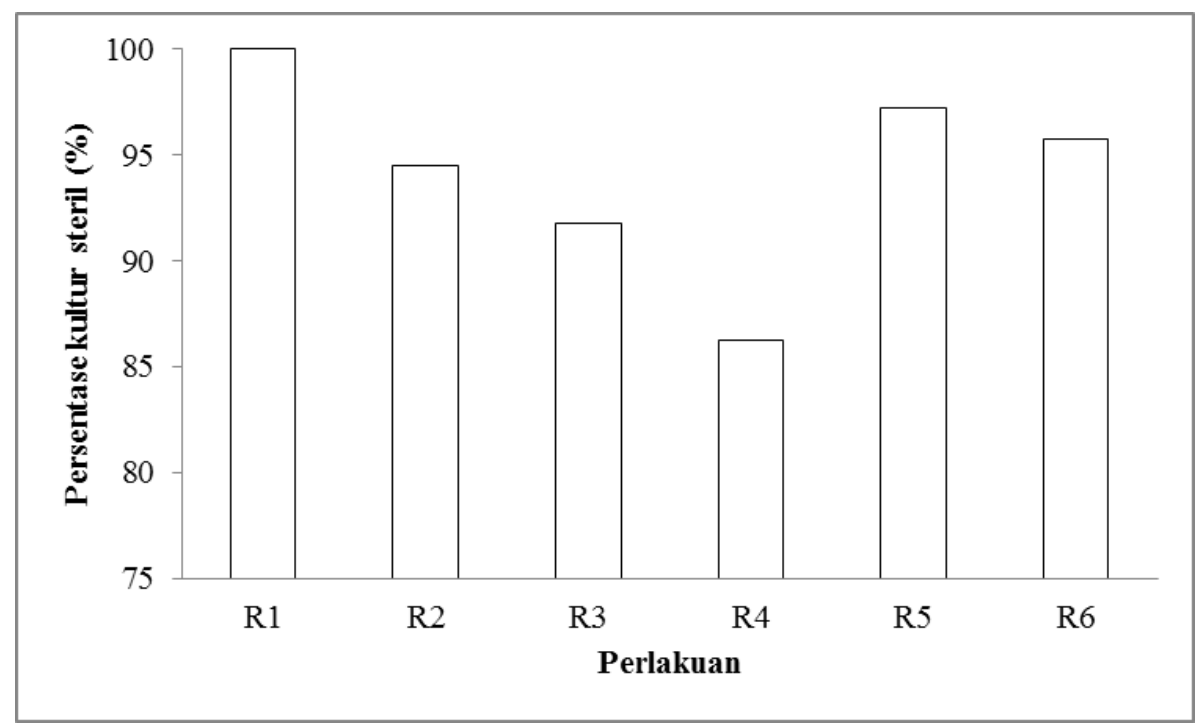

Gambar 1. Rata-rata persentase kultur steril umur 1-8 MST (\%)

$$
\begin{aligned}
& \mathrm{R} 1=5 \mathrm{mg} \mathrm{l}^{-1} 2.4-\mathrm{D} \\
& \left.\mathrm{R} 2=2.5 \mathrm{mg} \mathrm{l}^{-1} 2.4-\mathrm{D}\right) \\
& \mathrm{R} 3=5 \mathrm{mg} \mathrm{l}^{-1} 2.4-\mathrm{D}+1 \mathrm{mg} \mathrm{l}^{-1} \mathrm{BAP}
\end{aligned}
$$

Persentase kultur steril pada media R1 sebesar 100\% dari 50 satuan amatan (eksplan yang ditanam setiap perlakuan) pada umur kultur 1-8 minggu setelah tanam (MST). Kultur steril pada media R2, R3, R4, R5 dan R6 berturut-turut adalah $94.5 \%, 91.75 \%, 86.25 \%, 97.25 \%$ dan $95.75 \%$.
$\mathrm{R} 4=2.5 \mathrm{mg} \mathrm{l}^{-1} 2.4-\mathrm{D}+1 \mathrm{mg} \mathrm{l}^{-1} \mathrm{BAP}$

$\mathrm{R} 5=5 \mathrm{mg} \mathrm{l}^{-1} 2.4-\mathrm{D}+2 \mathrm{mg} \mathrm{l}^{-1} 2-\mathrm{iP}$

$\mathrm{R} 6=2.5 \mathrm{mg} \mathrm{l}^{-1} 2.4-\mathrm{D}+2 \mathrm{mg} \mathrm{l}^{-1} 2-\mathrm{iP}$

Secara umum tingkat kultur steril cukup tinggi, karena lebih dari $85 \%$. Selaras dengan hasil penelitian yang telah dilakukan oleh Rai et al. (2007) tingkat kontaminasi yang rendah pada semua media perlakuan disebabkan eksplan yang digunakan adalah biji. Secara morfologi posisi biji 
jambu biji merah terletak di dalam dan terlindungi oleh daging buah yang tebal sehingga terhindar dari kontak langsung dengan sumber kontaminan.

\section{Persentase Eksplan Berkalus}

Eksplan biji muda yang ditanam pada setiap perlakuan zat pengatur tumbuh mulai menunjukkan respon pembentukan kalus pada saat 1 MST. Tabel 1 menunjukkan komposisi zat pengatur tumbuh berpengaruh nyata terhadap persentase eksplan berkalus pada dua minggu pertama setelah penanaman. Eksplan yang ditanam pada media dengan perlakuan zat pengatur tumbuh R1, R3 dan R5 memiliki persentase pembentukan kalus lebih tinggi dibandingkan eksplan yang ditanam pada media R2, R4 dan R6.

Tabel 1. Pengaruh zat pengatur tumbuh terhadap persentase eksplan berkalus (\%)

\begin{tabular}{|c|c|c|c|c|c|c|}
\hline \multirow{2}{*}{ Perlakuan } & \multicolumn{6}{|c|}{ Eksplan berkalus (\%) } \\
\hline & $1 \mathrm{MS}$ & & $2 \mathrm{MS}$ & & $3 \mathrm{MST}$ & $4 \mathrm{MST}$ \\
\hline $\mathrm{R} 1\left(5 \mathrm{mg} \mathrm{l}^{-1} 2.4-\mathrm{D}\right)$ & 100.0 & $\mathrm{a}$ & 100.0 & $\mathrm{a}$ & 100.0 & 100.0 \\
\hline $\mathrm{R} 2\left(2.5 \mathrm{mg} \mathrm{l}^{-1} 2.4-\mathrm{D}\right)$ & 60.5 & $\mathrm{~b}$ & 74.5 & $\mathrm{~b}$ & 95.5 & 95.5 \\
\hline $\mathrm{R} 3\left(5 \mathrm{mg} \mathrm{l}^{-1} 2.4-\mathrm{D}+1 \mathrm{mg} \mathrm{l}^{-1} \mathrm{BAP}\right)$ & 87.0 & a & 91.5 & a & 100.0 & 100.0 \\
\hline $\mathrm{R} 4\left(2.5 \mathrm{mg} \mathrm{l}^{-1} 2.4-\mathrm{D}+1 \mathrm{mg} \mathrm{l}^{-1} \mathrm{BAP}\right)$ & 59.0 & $\mathrm{~b}$ & 74.6 & $\mathrm{~b}$ & 94.0 & 94.0 \\
\hline $\mathrm{R} 5\left(5 \mathrm{mg} \mathrm{l}^{-1} 2.4-\mathrm{D}+2 \mathrm{mg} \mathrm{l}^{-1} 2 \mathrm{ip}\right)$ & 90.0 & a & 100.0 & a & 100.0 & 100.0 \\
\hline $\mathrm{R} 6\left(2.5 \mathrm{mg} \mathrm{l}^{-1} 2.4-\mathrm{D}+2 \mathrm{mg} \mathrm{l}^{-1} 2 \mathrm{ip}\right)$ & 46.8 & $\mathrm{~b}$ & 71.2 & $\mathrm{~b}$ & 97.6 & 100.0 \\
\hline
\end{tabular}

Keterangan: Angka-angka yang diikuti oleh huruf yang sama pada kolom yang sama menunjukkan tidak berbeda nyata pada hasil uji lanjut DMRT taraf 5\%.

MST= Minggu setelah tanam

Media R1, R3 dan R5 mengandung konsentrasi zat pengatur tumbuh golongan auksin (2.4-D) yang lebih tinggi dibandingkan media R2, R4 dan R6. Media dengan konsentrasi auksin lebih tinggi akan menginduksi pembentukan kalus dan menekan morfogenesis. Menurut Yuwono (2006) pemberian senyawa 2.4-D pada media kultur jaringan selain akan meningkatkan kecepatan pembentukan kalus juga akan menekan organogenesis. Zulkarnain (2009) menambahkan senyawa 2.4-D diketahui dapat menginduksi perbanyakan sel tetapi menekan diferensiasi pada tanaman dikotil seperti jambu biji merah.

Media tanpa sitokinin maupun media dengan tambahan sitokinin BAP atau 2-iP ternyata tidak memperlihatkan respon yang berbeda terhadap persentase kalus yang terbentuk pada umur kultur 1-2 MST. Perbedaan jenis dan konsentrasi sitokinin yang dikandung oleh media R1, R3 dan R5 tidak memengaruhi persentase kalus yang terbentuk. Sama halnya dengan pengaruh perbedaan jenis dan konsentrasi sitokinin yang dikandung oleh media R2, R4 dan R6 ternyata persentase kalus yang terbentuk tidak berbeda nyata. Menurut Yuwono (2006) zat pengatur tumbuh yang memiliki peran dominan dalam proses pembentukan kalus adalah auksin dibandingkan dengan sitokinin.
Persentase eksplan berkalus pada semua perlakuan komposisi zat pengatur tumbuh memasuki umur kultur 3 MST tidak berbeda nyata berdasarkan hasil pengujian sidik ragam. R1 merupakan media paling efisien dalam penggunaan zat pengatur tumbuh yang memberikan respon terbaik terhadap persentase pembentukan kalus pada 1-2 MST. Sedangkan memasuki umur kultur 3 MST, R2 merupakan media paling efisien dalam penggunaan zat pengatur tumbuh yang memberikan respon terbaik terhadap persentase pembentukan kalus.

\section{Tipe Kalus}

Kalus merupakan kumpulan sel yang tidak terorganisir dan terjadi karena pembelahan yang sangat aktif. Rangsangan dari hormon endogen atau zat pengatur tumbuh yang ditambahkan (eksogen) menyebabkan metabolisme sel menjadi aktif, dalam keadaan demikian jaringan dikatakan sedang mengalami dediferensiasi. Keadaan ini terus berlangsung selama proliferasi kalus (Wetter dan Constabel 1991).

Terdapat dua tipe kalus yang terlihat pada percobaan ini. Tipe pertama yaitu kalus putih kehijauan yang memiliki ciri-ciri struktur kalusnya kompak dan tumbuh secara berkelompok di salah 
satu sisi eksplan (kalus kompak). Kalus tipe dua berwarna putih kecoklatan (krem), struktur kalusnya remah dan menyebar di seluruh permukaan eksplan (kalus remah).

Menurut Rai et al. (2007) kalus yang berasal dari eksplan biji muda jambu biji varietas lokal Banarasi (India) memiliki 2 tipe kalus, tipe pertama kalus putih yang jika dilihat di bawah mikroskop selnya terlihat memanjang dan saling bertumpukan menyatu, dari kumpulan kalus tipe ini tidak pernah ada yang berkembang menjadi embrio somatik. Kalus kompak dengan ciri-ciri tersebut berpotensi untuk berkembang ke arah organogenesis. Tipe kedua terdiri atas sel-sel bulat berwarna coklat terang hingga coklat gelap dan friable (remah). Kumpulan sel tipe ini seringkali ditemukan berasosiasi dengan embrio somatik.

Perbedaan sifat kalus dipengaruhi oleh komposisi zat pengatur tumbuh yang terkandung dalam media kultur jaringan. Hasil uji DMRT pada Tabel 2 menunjukkan bahwa media dengan komposisi zat pengatur tumbuh pada perlakuan R1 (5 mg l-1 2.4-D), R3 (5 mg l-1 2.4-D + $1 \mathrm{mg} \mathrm{l}^{-1}$ BAP) dan R6 (2.5 $\mathrm{mg} \mathrm{l}^{-1} 2.4-\mathrm{D}+2 \mathrm{mg} \mathrm{l}^{-1} 2$-iP) merupakan media terbaik untuk menginduksi kalus kompak pada umur kultur 4 MST. Sedangkan media dengan perlakuan zat pengatur tumbuh R5 (5 $\mathrm{mg} \mathrm{l}^{-1} 2.4-\mathrm{D}+2 \mathrm{mg} \mathrm{l}^{-1}$ 2-iP) merupakan media terbaik untuk menginduksi kalus remah.

Tabel 2. Pengaruh zat pengatur tumbuh terhadap tipe kalus pada 4 MST

\begin{tabular}{|c|c|c|c|c|}
\hline \multirow{2}{*}{ Perlakuan } & \multicolumn{4}{|c|}{ Tipe kalus (\%) } \\
\hline & Komp & & Rem & \\
\hline $\mathrm{R} 1$ (5 mg l-1 2.4-D) & 100.0 & a & 0.0 & $\mathrm{c}$ \\
\hline $\mathrm{R} 2\left(2.5 \mathrm{mg} \mathrm{l}^{-1} 2.4-\mathrm{D}\right)$ & 68.0 & $\mathrm{~b}$ & 27.5 & $\mathrm{~b}$ \\
\hline $\mathrm{R} 3\left(5 \mathrm{mg} \mathrm{l}^{-1} 2.4-\mathrm{D}+1 \mathrm{mg} \mathrm{l}^{-1} \mathrm{BAP}\right)$ & 100.0 & $\mathrm{a}$ & 0.0 & $\mathrm{c}$ \\
\hline $\mathrm{R} 4\left(2.5 \mathrm{mg} \mathrm{l}^{-1} 2.4-\mathrm{D}+1 \mathrm{mg} \mathrm{l}^{-1} \mathrm{BAP}\right)$ & 62.4 & $\mathrm{~b}$ & 31.6 & $\mathrm{~b}$ \\
\hline $\mathrm{R} 5\left(5 \mathrm{mg} \mathrm{l}^{-1} 2.4-\mathrm{D}+2 \mathrm{mg} \mathrm{l}^{-1} 2 \mathrm{ip}\right)$ & 40.0 & $\mathrm{c}$ & 60.0 & a \\
\hline $\mathrm{R} 6\left(2.5 \mathrm{mg} \mathrm{l}^{-1} 2.4-\mathrm{D}+2 \mathrm{mg} \mathrm{l}^{-1} 2 \mathrm{ip}\right)$ & 100.0 & $\mathrm{a}$ & 0.0 & $\mathrm{c}$ \\
\hline
\end{tabular}

Keterangan: Angka-angka yang diikuti oleh huruf yang sama pada kolom yang sama menunjukkan tidak berbeda nyata pada hasil uji lanjut DMRT taraf 5\%.

\section{Percobaan 2: Induksi Embrio Somatik}

Percobaan kedua merupakan percobaan yang menggunakan kalus yang terbentuk pada percobaan pertama. Seluruh kalus hasil percobaan pertama dipindahkan ke media yang berbeda, dengan lima taraf komposisi zat pengatur tumbuh pada umur kultur 8 MST.

Proses regenerasi tanaman secara in vitro dipengaruhi oleh dua faktor utama yaitu komponen media dan sumber eksplan (Rai et al. 2009). Komponen media yang memengaruhi proses regenerasi tanaman secara in vitro salah satunya adalah komposisi zat pengatur tumbuh (Taji et al. 2002). Morfogenesis kalus tergantung pada keseimbangan auksin dan sitokinin di dalam media. Interaksi antara zat pengatur tumbuh endogen tanaman dan zat pengatur tumbuh eksogen yang diserap dalam media akan menentukan arah perkembangan kalus (Asnawati et al. 2002).

Hasil pengamatan pada Tabel 3 menunjukkan persentase kalus berakar (KA), persentase eksplan berkecambah (KK), persentase kalus embriogenik (KE) dan jumlah embrio somatik yang terbentuk (ES) pada umur kultur 12, 14 dan 16 MST.

\section{Kalus Berakar}

Kultur kalus yang dikembangkan dari eksplan dapat diregenerasikan sehingga membentuk tanaman yang lengkap. Proses pembentukan organ-organ tanaman seperti akar dan tunas maupun tanaman yang lengkap dari kultur sel atau jaringan disebut dengan organogenesis (Yuwono 2006). Hasil kalus berakar yang didapatkan pada percobaaan ini tidak diharapkan. Kalus berakar lebih sulit diregenerasikan menjadi tanaman (Zulkarnain 2009).

Hasil pengamatan pada Tabel 3 menunjukkan terdapat empat perlakuan asal kalus dan zat pengatur tumbuh yang menginduksi terbentuknya kalus berakar. Semua perlakuan yang menghasilkan kalus berakar mengandung komposisi zat pengatur tumbuh tunggal yaitu auksin, baik itu 2.4-D maupun NAA. Perlakuan 
R1E2 (kalus dari media MS + $5 \mathrm{mg} \mathrm{l}^{-1}$ 2.4-D dipindahkan ke media MS + $1 \mathrm{mg} \mathrm{l}^{-1} 2.4-\mathrm{D}+1 \mathrm{mg}$ $1^{-1}$ NAA) dapat menghasilkan persentase tertinggi kalus berakar pada umur kultur 12-16 MST. Menurut Wetter dan Constabel (1991) pembentukan organ (organogenesis) pada kultur in vitro tanaman dipengaruhi oleh ketersediaan senyawa-senyawa tertentu dalam media. Pembentukan tunas dan akar ditentukan oleh konsentrasi auksin dan sitokinin yang digunakan. Dominasi auksin yang lebih tinggi dibandingkan dengan sitokinin dapat menginduksi terbentuknya akar.

Tabel 3. Pengaruh asal kalus dan zat pengatur tumbuh terhadap persentase kalus berakar, eksplan berkecambah, kalus embriogenik dan jumlah embrio somatik

\begin{tabular}{|c|c|c|c|c|c|c|c|c|c|c|c|c|c|}
\hline \multirow{2}{*}{$\begin{array}{c}\text { Asal } \\
\text { Media }\end{array}$} & \multirow{2}{*}{$\begin{array}{c}\text { Media } \\
\text { Subkultur }\end{array}$} & \multicolumn{4}{|c|}{$12 \mathrm{MST}$} & \multicolumn{3}{|c|}{14 MST } & \multicolumn{5}{|c|}{$16 \mathrm{MST}$} \\
\hline & & $\begin{array}{l}\text { KA } \\
(\%)\end{array}$ & $\begin{array}{l}\text { KK } \\
(\%)\end{array}$ & $\begin{array}{l}\mathrm{KE} \\
(\%)\end{array}$ & ES & $\begin{array}{l}\text { KA } \\
(\%)\end{array}$ & $\begin{array}{l}\mathrm{KK} \\
(\%)\end{array}$ & $\begin{array}{l}\mathrm{KE} \\
(\%)\end{array}$ & ES & $\begin{array}{l}\text { KA } \\
(\%)\end{array}$ & $\begin{array}{l}\text { KK } \\
(\%)\end{array}$ & $\begin{array}{l}\mathrm{KE} \\
(\%)\end{array}$ & ES \\
\hline \multirow{5}{*}{ R1 } & E1 & 36.7 & 0.0 & 0.0 & 0 & 56.7 & 0.0 & 0.0 & 0 & 63.3 & 0.0 & 0.0 & 0 \\
\hline & E2 & 46.7 & 0.0 & 0.0 & 0 & 63.3 & 0.0 & 0.0 & 0 & 80.0 & 0.0 & 0.0 & 0 \\
\hline & E3 & 0.0 & 0.0 & 0.0 & 0 & 0.0 & 0.0 & 0.0 & 0 & 0.0 & 0.0 & 0.0 & 0 \\
\hline & E4 & 0.0 & 0.0 & 0.0 & 0 & 0.0 & 0.0 & 0.0 & 0 & 0.0 & 0.0 & 0.0 & 0 \\
\hline & E5 & 0.0 & 50.0 & 0.0 & 0 & 0.0 & 90.0 & 0.0 & 0 & 0.0 & 90.0 & 0.0 & 0 \\
\hline \multirow{5}{*}{ R2 } & E1 & 10.0 & 0.0 & 0.0 & 0 & 30.0 & 0.0 & 0.0 & 0 & 56.7 & 0.0 & 0.0 & 0 \\
\hline & E2 & 20.0 & 0.0 & 0.0 & 0 & 56.7 & 0.0 & 0.0 & 0 & 66.7 & 0.0 & 0.0 & 0 \\
\hline & E3 & 0.0 & 0.0 & 0.0 & 0 & 0.0 & 0.0 & 0.0 & 2 & 0.0 & 0.0 & 0.0 & 2 \\
\hline & E4 & 0.0 & 0.0 & 26.7 & 2 & 0.0 & 0.0 & 26.7 & 2 & 0.0 & 0.0 & 26.7 & 2 \\
\hline & E5 & 0.0 & 36.7 & 0.0 & 0 & 0.0 & 83.3 & 0.0 & 0 & 0.0 & 83.3 & 0.0 & 0 \\
\hline \multirow{5}{*}{ R3 } & E1 & 0.0 & 0.0 & 0.0 & 0 & 0.0 & 0.0 & 0.0 & 0 & 0.0 & 0.0 & 0.0 & 0 \\
\hline & E2 & 0.0 & 0.0 & 0.0 & 0 & 0.0 & 0.0 & 0.0 & 0 & 0.0 & 0.0 & 0.0 & 0 \\
\hline & E3 & 0.0 & 0.0 & 0.0 & 0 & 0.0 & 0.0 & 0.0 & 0 & 0.0 & 0.0 & 0.0 & 0 \\
\hline & E4 & 0.0 & 0.0 & 0.0 & 0 & 0.0 & 0.0 & 0.0 & 0 & 0.0 & 0.0 & 0.0 & 0 \\
\hline & E5 & 0.0 & 26.7 & 0.0 & 0 & 0.0 & 73.3 & 0.0 & 0 & 0.0 & 83.3 & 0.0 & 0 \\
\hline \multirow{5}{*}{ R4 } & E1 & 0.0 & 0.0 & 0.0 & 0 & 0.0 & 0.0 & 0.0 & 0 & 0.0 & 0.0 & 0.0 & 0 \\
\hline & E2 & 0.0 & 0.0 & 0.0 & 0 & 0.0 & 0.0 & 0.0 & 0 & 0.0 & 0.0 & 0.0 & 0 \\
\hline & E3 & 0.0 & 0.0 & 21.7 & 0 & 0.0 & 0.0 & 21.7 & 0 & 0.0 & 0.0 & 21.7 & 0 \\
\hline & E4 & 0.0 & 0.0 & 33.3 & 0 & 0.0 & 0.0 & 33.3 & 0 & 0.0 & 0.0 & 33.3 & 0 \\
\hline & E5 & 0.0 & 30.0 & 0.0 & 0 & 0.0 & 66.7 & 0.0 & 0 & 0.0 & 90.0 & 0.0 & 0 \\
\hline \multirow{5}{*}{ R5 } & E1 & 0.0 & 0.0 & 11.7 & 0 & 0.0 & 0.0 & 11.7 & 0 & 0.0 & 0.0 & 11.7 & 4 \\
\hline & E2 & 0.0 & 0.0 & 0.0 & 0 & 0.0 & 0.0 & 0.0 & 0 & 0.0 & 0.0 & 0.0 & 0 \\
\hline & E3 & 0.0 & 0.0 & 53.3 & 0 & 0.0 & 0.0 & 53.3 & 0 & 0.0 & 0.0 & 53.3 & 0 \\
\hline & E4 & 0.0 & 0.0 & 60.0 & 0 & 0.0 & 0.0 & 60.0 & 0 & 0.0 & 0.0 & 60.0 & 32 \\
\hline & E5 & 0.0 & 30.0 & 0.0 & 0 & 0.0 & 80.0 & 0.0 & 0 & 0.0 & 80.0 & 0.0 & 0 \\
\hline \multirow{5}{*}{ R6 } & $\overline{E 1}$ & 0.0 & 0.0 & 0.0 & 0 & 0.0 & 0.0 & 0.0 & 0 & 0.0 & 0.0 & 0.0 & 0 \\
\hline & E2 & 0.0 & 0.0 & 0.0 & 0 & 0.0 & 0.0 & 0.0 & 0 & 0.0 & 0.0 & 0.0 & 0 \\
\hline & E3 & 0.0 & 0.0 & 0.0 & 0 & 0.0 & 0.0 & 0.0 & 0 & 0.0 & 0.0 & 0.0 & 0 \\
\hline & E4 & 0.0 & 0.0 & 0.0 & 0 & 0.0 & 0.0 & 0.0 & 0 & 0.0 & 0.0 & 0.0 & 0 \\
\hline & E5 & 0.0 & 46.7 & 0.0 & 0 & 0.0 & 76.7 & 0.0 & 0 & 0.0 & 93.3 & 0.0 & 0 \\
\hline
\end{tabular}

Keterangan:

$\mathrm{KA}=$ Persentase kalus berakar

$\mathrm{KK}=$ Persentase eksplan

berkecambah

$\mathrm{KE}=$ Persentase kalus embriogenik

ES = Jumlah embrio somatik

MST $=$ Minggu setelah tanam
$\mathrm{R} 1=5 \mathrm{mg} \mathrm{l}^{-1} 2.4-\mathrm{D}$

$\mathrm{E} 2=1 \mathrm{mg} \mathrm{l}^{-1} 2.4-\mathrm{D}+1 \mathrm{mg} \mathrm{l}^{-1} \mathrm{NAA}$

$\mathrm{R} 3=5 \mathrm{mg} \mathrm{l}^{-1} 2.4-\mathrm{D}+1 \mathrm{mg} \mathrm{l}^{-1} \mathrm{BAP}$

$\mathrm{R} 4=2.5 \mathrm{mg} \mathrm{l}^{-1} 2.4-\mathrm{D}+1 \mathrm{mg} \mathrm{l}^{-1} \mathrm{BAP}$

$\mathrm{R} 5=5 \mathrm{mg} \mathrm{l}^{-1} 2.4-\mathrm{D}+2 \mathrm{mg} \mathrm{l}^{-1} 2-\mathrm{iP}$

$\mathrm{R} 6=2.5 \mathrm{mg} \mathrm{l}^{-1} 2.4-\mathrm{D}+2 \mathrm{mg} \mathrm{l}^{-1} 2-\mathrm{iP}$
$\mathrm{E} 1=1 \mathrm{mg} \mathrm{l}^{-1} 2.4-\mathrm{D}$

$\mathrm{R} 2=2.5 \mathrm{mg} \mathrm{l}^{-1} 2.4-\mathrm{D}$

$\mathrm{E} 3=1 \mathrm{mg} \mathrm{l}^{-1} 2.4-\mathrm{D}+1 \mathrm{mg} \mathrm{l}^{-1} \mathrm{BAP}$

$\mathrm{E} 4=1 \mathrm{mg} \mathrm{l}^{-1} 2.4-\mathrm{D}+2 \mathrm{mg} \mathrm{l}^{-1} 2-\mathrm{iP}$

$\mathrm{E} 5=1 \mathrm{mg} \mathrm{l}^{-1} 2.4-\mathrm{D}+1 \mathrm{mg} \mathrm{l}^{-1} \mathrm{GA} 3$ 

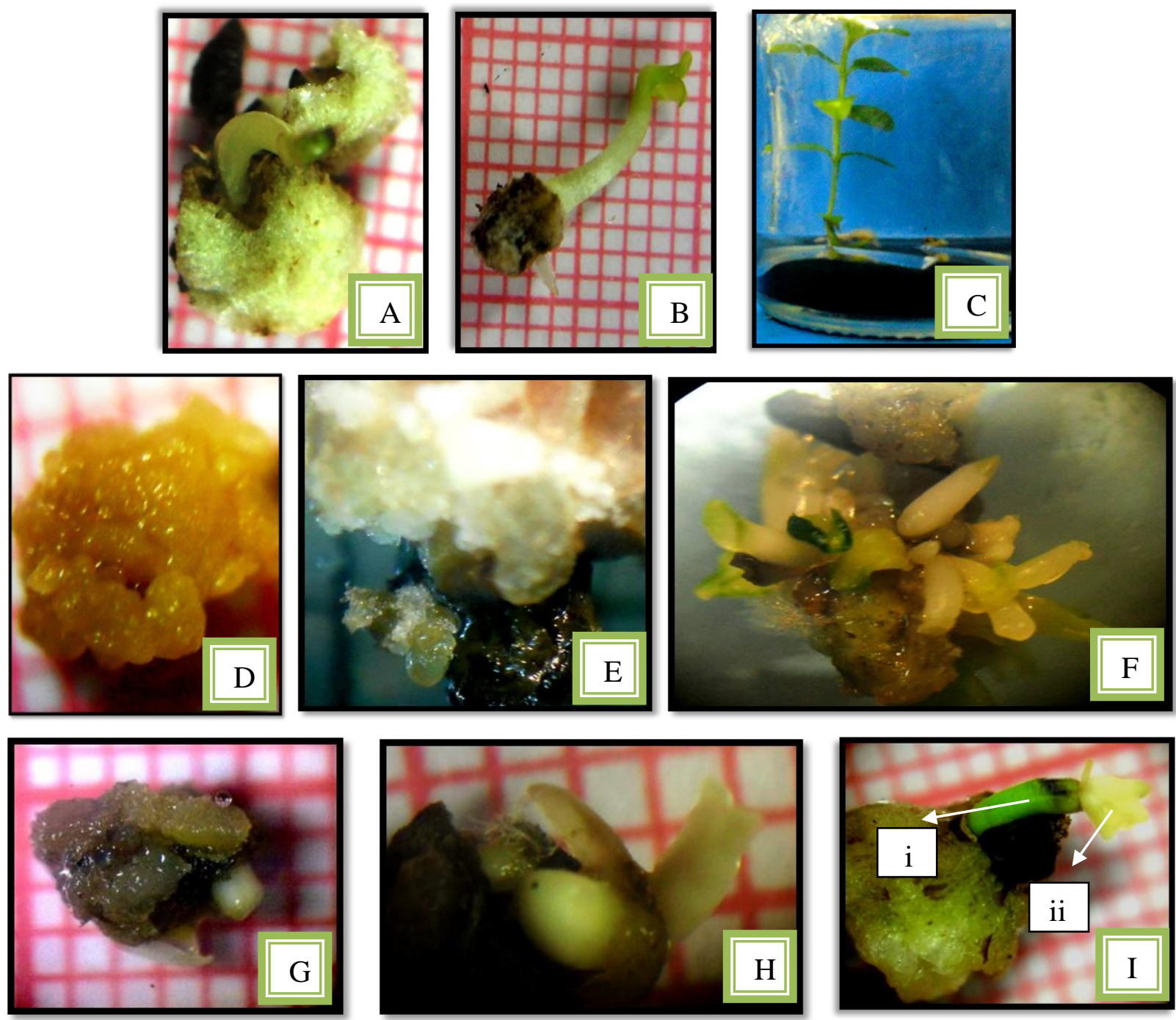

Gambar 2. A) Embrio zigotik yang berkecambah pada perlakuan R6E5 12 MST. B) Embrio zigotik yang berkecambah pada perlakuan R6E5 14 MST. C) Tunas mikro jambu biji merah 16 MST. D) Kalus embriogenik pada perlakuan R5E3 14 MST. E) Embrio somatik primer pada perlakuan R2E4 12 MST. F) Embrio somatik primer pada perlakuan R5E4 16 MST. G) Embrio zigotik pada perlakuan R5E1 12 MST. H) Embrio somatik sekunder pada perlakuan R5E1 16 MST. I) (i) Embrio zigotik dan (ii) embrio somatik sekunder pada perlakuan R2E3 14 MST.

\section{Eksplan Berkecambah}

Kecambah yang muncul pada percobaan ini merupakan kecambah yang berasal dari embrio zigotik. Eksplan yang berasal dari biji muda memiliki potensi untuk berkecambah pada media yang tepat. Hasil pengamatan pada Tabel 3 menunjukkan terdapat enam perlakuan asal kalus dan zat pengatur tumbuh yang menginduksi terbentuknya eksplan berkecambah. Persentase eksplan berkecambah pada keenam perlakuan (R1E5, R2E5, R3E5, R4E5, R5E5 dan R6E5) relatif tinggi $\geq 80 \%$ pada umur kultur 16 MST.

Semua perlakuan yang menginduksi munculnya kecambah mengandung komposisi zat pengatur tumbuh $1 \mathrm{mg} \mathrm{l}^{-1} \mathrm{GA} 3$. Secara umum peranan giberelin di dalam tanaman adalah untuk meningkatkan perkecambahan biji dan menginduksi pemanjangan ruas. Selain itu giberelin dapat dimanfaatkan untuk menginduksi pembentukan embrio dari kalus (Zulkarnain 2009). Namun pada percobaan ini kalus yang disubkultur pada media yang mengandung giberelin tidak terinduksi untuk membentuk embrio melainkan terinduksi untuk berkecambah dari eksplan awal berupa biji. Gambar 2A, 2B dan 2C menunjukkan perkembangan proses perkecambahan embrio zigotik pada media dengan perlakuan zat pengatur tumbuh R6E5 (kalus dari media $\mathrm{MS}+2.5 \mathrm{mg} \mathrm{l}^{-1}$ 2.4-D + $2 \mathrm{mg} \mathrm{l}^{-1}$ 2-iP dipindahkan ke media MS + 
$1 \mathrm{mg} \mathrm{l}^{-1} 2.4-\mathrm{D}+1 \mathrm{mg} \mathrm{l}^{-1} \mathrm{GA} 3$ ) pada saat umur kultur 12, 14 dan 16 MST.

Perbedaan asal kalus yang berasal dari percobaan pertama memberikan perbedaan yang nyata terhadap rata-rata tinggi kecambah pada percobaan kedua. Tabel 4 menunjukkan bahwa perlakuan R6E5 menghasilkan rata-rata tinggi kecambah tertinggi pada umur kultur 12-14 MST.

Tabel 4. Pengaruh asal kalus terhadap rata-rata tinggi kecambah

\begin{tabular}{|c|c|c|c|c|c|c|c|c|}
\hline \multirow{2}{*}{ Perlakuan } & \multicolumn{8}{|c|}{ Rata-rata tinggi kecambah $(\mathrm{cm})$} \\
\hline & \multicolumn{2}{|c|}{$12 \mathrm{MST}$} & \multicolumn{2}{|l|}{$13 \mathrm{MST}$} & \multicolumn{2}{|c|}{$14 \mathrm{MST}$} & \multirow{2}{*}{$\begin{array}{c}15 \mathrm{MST} \\
2.24\end{array}$} & \multirow{2}{*}{$\begin{array}{c}16 \mathrm{MST} \\
3.10\end{array}$} \\
\hline R1E5 & 0.34 & $\mathrm{ab}$ & 0.60 & $\mathrm{~b}$ & 1.50 & $\mathrm{~b}$ & & \\
\hline R2E5 & 0.28 & $a b$ & 0.64 & $\mathrm{~b}$ & 1.62 & $\mathrm{~b}$ & 2.30 & 3.06 \\
\hline R3E5 & 0.24 & $\mathrm{ab}$ & 0.56 & $\mathrm{~b}$ & 1.22 & $\mathrm{~b}$ & 2.38 & 3.14 \\
\hline R4E5 & 0.24 & $a b$ & 0.54 & $\mathrm{~b}$ & 1.28 & $\mathrm{~b}$ & 2.10 & 3.18 \\
\hline R5E5 & 0.16 & $\mathrm{~b}$ & 0.56 & $\mathrm{~b}$ & 1.38 & $a b$ & 2.26 & 3.22 \\
\hline R6E5 & 0.44 & $\mathrm{a}$ & 1.02 & $\mathrm{a}$ & 1.98 & $\mathrm{a}$ & 2.84 & 3.56 \\
\hline
\end{tabular}

Keterangan: Angka-angka yang diikuti oleh huruf yang sama pada kolom yang sama menunjukkan tidak berbeda nyata pada hasil uji lanjut DMRT taraf $5 \%$.

$\mathrm{R} 1=5 \mathrm{mg} \mathrm{l}^{-1} 2.4-\mathrm{D}$

$\mathrm{R} 2=2.5 \mathrm{mg} \mathrm{l}^{-1} 2.4-\mathrm{D}$

$\mathrm{R} 3=5 \mathrm{mg} \mathrm{l}^{-1} 2.4-\mathrm{D}+1 \mathrm{mg} \mathrm{l}^{-1} \mathrm{BAP}$

$\mathrm{R} 4=2.5 \mathrm{mg} \mathrm{l}^{-1} 2.4-\mathrm{D}+1 \mathrm{mg} \mathrm{l}^{-1} \mathrm{BAP}$

\section{Kalus Embriogenik}

Eksplan dapat ditumbuhkan sebagai kalus yang selanjutnya dikembangkan untuk menghasilkan embrio somatik. Embrio somatik dapat diinduksi sehingga berkecambah dan akhirnya menjadi plantlet. Kalus yang memiliki sifat untuk dikembangkan menjadi embrio disebut dengan kalus embriogenik. Proses pembentukan embrio dari sel somatik seperti kalus disebut dengan embriogenesis somatik (Evans et al. 2003). Gambar 2D menunjukkan contoh kalus embriogenik pada perlakuan R5E3 (kalus dari media $\mathrm{MS}+5 \mathrm{mg} \mathrm{l}^{-1} 2.4-\mathrm{D}+2 \mathrm{mg} \mathrm{l}^{-1} 2-\mathrm{iP}$ dipindahkan ke media MS + $1 \mathrm{mg} \mathrm{l}^{-1} 2.4-\mathrm{D}+1 \mathrm{mg}$ $\left.\mathrm{l}^{-1} \mathrm{BAP}\right)$ pada umur kultur $14 \mathrm{MST}$.

Hasil pengamatan pada Tabel 3 menunjukkan terdapat lima perlakuan asal kalus dan zat pengatur tumbuh yang menginduksi terbentuknya kalus yang bersifat embriogenik. Perlakuan R5E4 (kalus dari media MS $+5 \mathrm{mg} \mathrm{l}^{-1}$ 2.4-D + $2 \mathrm{mg} \mathrm{l}^{-1}$ 2-iP dipindahkan ke media MS + $1 \mathrm{mg} \mathrm{l}^{-1} 2.4-\mathrm{D}+2 \mathrm{mg} \mathrm{l}^{-1} 2$ 2-iP) merupakan perlakuan yang memiliki persentase kalus embriogenik tertinggi pada umur kultur 12-16 MST yakni sekitar 60\%. Menurut Moura dan Motoike (2009) penggunaan sitokinin dan auksin pada media MS secara bersamaan dapat memacu terbentuknya kalus embriogenik pada biji muda tanaman jambu biji varietas paluma yang berasal dari Brazil. Hasil penelitian mereka menunjukkan persentase terbesar pembentukan kalus

$$
\begin{aligned}
& \mathrm{R} 5=5 \mathrm{mg} \mathrm{l}^{-1} 2.4-\mathrm{D}+2 \mathrm{mg} \mathrm{l}^{-1} 2-\mathrm{iP} \\
& \mathrm{R} 6=2.5 \mathrm{mg} \mathrm{l}^{-1} 2.4-\mathrm{D}+2 \mathrm{mg} \mathrm{l}^{-1} 2-\mathrm{iP} \\
& \mathrm{E} 5=1 \mathrm{mg} \mathrm{l}^{-1} 2.4-\mathrm{D}+1 \mathrm{mg} \mathrm{l}^{-1} \mathrm{GA} 3 \\
& \mathrm{MST}=\text { Minggu setelah tanam }
\end{aligned}
$$

embriogenik terdapat pada media MS yang ditambah dengan $1 \mathrm{mg} \mathrm{l}^{-1} 2.4-\mathrm{D}+2 \mathrm{mg} \mathrm{l}^{-1} 2$-iP, selaras dengan hasil yang didapat pada Tabel 3 .

\section{Embrio Somatik}

Kalus embriogenik yang terbentuk memiliki potensi untuk menghasilkan embrio somatik baik secara langsung (embrio somatik primer) maupun secara tidak langsung (embrio somatik sekunder). Embrio somatik primer merupakan embrio somatik yang dihasilkan langsung dari kalus yang bersifat embriogenik, sedangkan embrio somatik sekunder merupakan embrio somatik yang terbentuk di atas permukaan embrio zigotik yang berasal dari eksplan biji muda yang ditanam.

Menurut Zulkarnain (2009) sama seperti embrio zigotik yang berkembang dari penyatuan gamet jantan dan gamet betina, embrio somatik pun tumbuh dan berkembang melewati tahapantahapan yang sama. Tahapan-tahapan tersebut adalah globular, hati, torpedo, dan kotiledon. Embrio somatik mempunyai ciri struktur bipolar dengan dua calon meristem, yaitu meristem akar dan meristem tunas.

Embrio somatik primer terbentuk pada dua perlakuan yaitu R2E4 dan R5E4. Perlakuan R2E4 (kalus dari media $\mathrm{MS}+2.5 \mathrm{mg} \mathrm{l}^{-1}$ 2.4-D dipindahkan ke media MS + $1 \mathrm{mg} \mathrm{l}^{-1} 2.4-\mathrm{D}+2 \mathrm{mg}$ $\left.\mathrm{l}^{-1} \quad 2-\mathrm{iP}\right)$ dapat menginduksi terbentuknya dua embrio somatik primer (fase globular dan fase 
hati) pada umur kultur 12 MST (Gambar 2E). Perlakuan R5E4 (kalus dari media MS $+5 \mathrm{mg} \mathrm{l}^{-1}$ 2.4-D + $2 \mathrm{mg} \mathrm{l}^{-1}$ 2-iP dipindahkan ke media MS + $1 \mathrm{mg} \mathrm{l}^{-1}$ 2.4-D + $2 \mathrm{mg} \mathrm{l}^{-1} 2$-iP) dapat menginduksi terbentuknya 32 embrio somatik primer (enam fase globular, empat fase hati, 17 fase torpedo dan lima fase kotiledon) pada umur kultur 16 MST (Gambar 2F).

Embrio somatik sekunder terbentuk pada dua perlakuan yaitu R5E1 dan R2E3. Perlakuan R5E1 (kalus dari media MS + $5 \mathrm{mg} \mathrm{l}^{-1} 2.4-\mathrm{D}+2$ $\mathrm{mg} \mathrm{l}^{-1}$ 2-iP dipindahkan ke media MS $+1 \mathrm{mg} \mathrm{l}^{-1}$ 2.4-D) dapat menginduksi terbentuknya embrio zigotik pada umur kultur 12 MST (Gambar 2G) dan embrio somatik sekunder terbentuk pada umur kultur 16 MST (Gambar 2H). Perlakuan R2E3 (kalus dari media MS + $2.5 \mathrm{mg} \mathrm{l}^{-1}$ 2.4-D dipindahkan ke media MS + $1 \mathrm{mg} \mathrm{l}^{-1} 2.4-\mathrm{D}+1 \mathrm{mg}$ $\left.\mathrm{l}^{-1} \mathrm{BAP}\right)$ dapat menginduksi terbentuknya embrio somatik sekunder pada umur kultur 14 MST (Gambar 2I).

\section{KESIMPULAN}

Media dengan perlakuan zat pengatur tumbuh R1 (5 $\mathrm{mg} \mathrm{l}^{-1}$ 2.4-D), R3 (5 $\mathrm{mg} \mathrm{l}^{-1}$ 2.4-D + 1 $\left.\mathrm{mg} \mathrm{l}^{-1} \mathrm{BAP}\right)$ dan R5 (5 $\mathrm{mg} \mathrm{l}^{-1} 2.4-\mathrm{D}+2 \mathrm{mg} \mathrm{l}^{-1} 2$-iP) merupakan perlakuan terbaik untuk menginduksi kalus pada 1-2 MST. R1 merupakan media paling efisien dalam penggunaan zat pengatur tumbuh yang memberikan respon terbaik terhadap persentase pembentukan kalus pada 1-2 MST. Setelah memasuki umur kultur 3 MST, R2 (2.5 mg $\left.\mathrm{I}^{-1} 2.4-\mathrm{D}\right)$ merupakan media paling efisien dalam penggunaan zat pengatur tumbuh yang memberikan respon terbaik terhadap persentase pembentukan kalus. Media dengan perlakuan zat pengatur tumbuh R1, R3 dan R6 (2.5 $\mathrm{mg} \mathrm{l}^{-1}$ 2.4-D $+2 \mathrm{mg} \mathrm{l}^{-1}$ 2-iP) merupakan perlakuan terbaik untuk menginduksi kalus kompak pada 4 MST, sedangkan untuk menginduksi kalus remah didapatkan media dengan perlakuan zat pengatur tumbuh terbaik yaitu R5.

Perlakuan R2E4 (kalus dari media MS + $2.5 \mathrm{mg} \mathrm{l}^{-1}$ 2.4-D dipindahkan ke media $\mathrm{MS}+1 \mathrm{mg}$ $\mathrm{l}^{-1} 2.4-\mathrm{D}+2 \mathrm{mg} \mathrm{l}^{-1} 2$-iP) dan R5E4 (kalus dari media MS + $5 \mathrm{mg} \mathrm{l}^{-1} 2.4-\mathrm{D}+2 \mathrm{mg} \mathrm{l}^{-1} 2-\mathrm{iP}$ dipindahkan ke media MS + $1 \mathrm{mg} \mathrm{l}^{-1} 2.4-\mathrm{D}+2 \mathrm{mg}$ $\left.\mathrm{I}^{-1} 2-\mathrm{iP}\right)$ terbukti dapat menginduksi terbentuknya embrio somatik primer masing-masing pada 12 dan 16 MST. Embrio somatik sekunder didapatkan pada perlakuan R5E1 (kalus dari media MS +5 $\mathrm{mg} \mathrm{l}^{-1} 2.4-\mathrm{D}+2 \mathrm{mg} \mathrm{l}^{-1} 2$-iP dipindahkan ke media $\mathrm{MS}+1 \mathrm{mg} \mathrm{l}^{-1}$ 2.4-D) dan R2E3 (kalus dari media $\mathrm{MS}+2.5 \mathrm{mg} \mathrm{l}^{-1}$ 2.4-D dipindahkan ke media MS + $\left.1 \mathrm{mg} \mathrm{l}^{-1} 2.4-\mathrm{D}+1 \mathrm{mg} \mathrm{l}^{-1} \mathrm{BAP}\right)$ pada 16 dan 14 MST.

\section{DAFTAR PUSTAKA}

Asnawati, Wattimena G.A., Machmud M., Purwito A. 2002. Studi regenerasi dan produksi protoplas mesofil daun beberapa klon tanaman kentang (Solanum tuberosum L.). Bul.Agron. 30(3):87-91.

Cahyono, B. 2010. Mengenal Guava. Yogyakarta (ID): Lily.

Chandra, R., Bajpai A., Gupta S., Tiwari R.K. 2004. Embryogenesis and plant regeneration from mesocarp of Psidium guajava L. (guava). Indian $\mathrm{J}$ Biotech. 3(1):246-248.

Damayanti, D., Sudarsono, Mariska I., Herman M. 2007. Regenerasi pepaya melalui kultur in vitro. AgroBiogen. 3(2):49-54.

Evans, D.E., Coleman J.O.D., Kearns A. 2003. Plant Cell Culture. New York (US): Bios Scientific.

Lestari, E.G. 2007. Kultur Jaringan: Menjawab Persoalan Pemenuhan Kebutuhan akan Peningkatan Kualitas Bibit Unggul dan Perbanyakannya secara Besar-Besaran. Bogor (ID). Ganang Dwi Kartika Pr.

Moura, E.F., Motoike S.Y. 2009. Induction of somatic embryogenesis in immature seeds of guava tree cv. paluma. Bras. Frutic. 31(2):507-511.

Rai, M.K., Akhtar N., Jaiswal V.S. 2007. Somatic embryogenesis and plant regeneration in Psidium guajava L. cv. banarasi local. Scientia Horticulturae. 113(1):129-133.

Rai, M.K., Jaiswal V.S., Jaiswal U. 2009. Shoot multiplication and plant regeneration of guava (Psidium guajava L.) from nodal explants of in vitro raised plantlets. J. Fruit Ornam. Plants Res. 17(1):29-38.

Taji, A., Kumar P.P., Lakshmanan P. 2002. In Vitro Plant Breeding. New York (US): Food Products Pr.

Wetter, L.R., Constabel F. 1991. Metode Kultur Jaringan Tanaman. Widianto MB, penerjemah. Bandung (ID): ITB Pr. Terjemahan dari: Plant Tissue Culture Methods. 
Bul. Agrohorti 2(1) : 49 - 58 (2014)

Yuwono, T. 2006. Bioteknologi Pertanian. Yogyakarta (ID). Univ Gadjah Mada Pr.
Zulkarnain. 2009. Kultur Jaringan Tanaman: Solusi Perbanyakan Tanaman Budi Daya. Jakarta (ID): Bumi Aksara. 